\title{
Autoimmune disease of the gastro-intestinal tract
}

\author{
RALPH WRIGHT \\ Nuffield Department of Clinical Medicine, \\ University of Oxford
}

DURING the past decade it has become widely accepted that the body might, under certain circumstances, react immunologically to its own antigens in a way which is harmful to the organism. The mechanism whereby tissue damage occurs and the relationship between such autoimmune processes and immunological responses provoked by exogenous antigens remains uncertain. It would seem that both circulating antibody and immune processes directly mediated by cells, such as lymphocytes, may be involved.

A number of approaches have been used to study the pathogenesis of these diseases. Lesions resembling those seen in man have been produced in experimental animals by immunological means, but their relevance to human disease is difficult to assess. In man technical difficulties especially in regard to the in vitro measurement of delayed hypersensitivity responses has limited progress.

Much of the information available therefore relates to circulating autoantibodies. When considering the significance of such antibodies a number of questions arise:

(1) Are they a factor in pathogenesis?

(2) Are they a consequence of tissue damage?

(3) Are they an indirect association, either genetic or environmental?

(4) Are they of value in diagnosis?

The present discussion will be confined to an examination of the significance of these circulating antibodies in a number of disorders affecting the alimentary tract and liver and only passing reference will be made to attempts to evaluate the role of cell mediated immune responses, although these may well be of fundamental importance in pathogenesis.

\section{Pernicious anaemia and gastritis}

Two types of circulating autoantibody have been described in patients with pernicious anaemia. One, best detected by radioimmunoassay, is an antibody to intrinsic factor (Taylor, 1959; Schwartz, 1960 ; Ardeman \& Chanarin, 1963) and the other, best detected by immunofluorescence, is an antibody which reacts with gastric parietal cell cytoplasm (Taylor et al., 1962 ; Irvine, 1963).

Intrinsic factor antibodies are found in about $55 \%$ of patients with pernicious anaemia (Ardeman \& Chanarin, 1963; Coghill et al., 1965; Wangel \& Schiller, 1966) and only very rarely in other conditions. When intrinsic factor antibodies are found in the absence of overt pernicious anaemia they are almost invariably associated with malabsorption of vitamin $\mathbf{B}_{12}$ (Fisher et al., 1967).

Gastric parietal cell antibodies are present in the serum of over $80 \%$ of patients with pernicious anaemia and in a small proportion of apparently healthy subjects, their prevalence is increased in patients with thyroid disease (Doniach, Roitt \& Taylor, 1963), iron-deficiency anaemia (Dagg et al., 1966) idiopathic adrenal insufficiency and diabetes mellitus (Irvine et al., 1965) and Sjögrens syndrome (Buchanan et al., 1966). When gastric parietal cell antibodies occur in the serum a histological lesion of the stomach is present with impairment of gastric function (Adams et al., 1964). On the other hand severe gastric damage is not necessarily associated with the presence of such antibodies.

In an attempt to assess the significance of these immunological findings, we have made a blind correlative study of gastric mucosal structure and circulating parietal cell and intrinsic factor antibodies in 150 patients (Wright et al., 1966). Fig. 1 shows that the parietal cell antibody is rarely detected when the histology is normal but that its incidence increases with increasing severity of the gastritis. Intrinsic factor antibodies are usually found only in the more severe grades of gastritis and are much less common than parietal cell antibodies.

If the results for gastric parietal cell antibody are broken down according to diagnosis it can be seen that the antibody is found more commonly in patients who have gastric damage in association with iron-deficiency anaemia, pernicious anaemia or latent pernicious anaemia, than if the gastric damage occurs in association with a miscellaneous group of other diseases such 


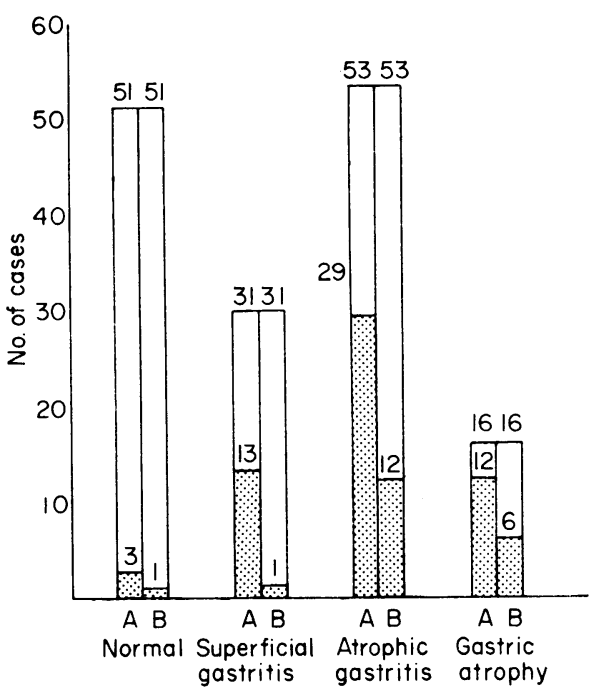

FIG. 1. The relationship of gastric parietal cell antibodies (A) and intrinsic factor antibodies (B) to the histology of the gastric mucosa (150 cases). Stippled columns, positive; open columns, negative. (Reproduced from Wright et al., 1966, by kind permission of the Editor.)

as ulcerative colitis, idiopathic steatorrhoea or following partial gastrectomy (Fig. 2). This is particularly striking if the prevalence of parietal cell antibody is compared in the diifferent groups of patients with atrophic gastritis. Two out of eighteen patients with atrophic gastritis in the miscellaneous group had parietal cell antibodies in their serum compared with five out of nine patients with 'idiopathic' iron-deficiency anaemia and ten out of thirteen patients with pernicious anaemia or latent perncious anaemia. In other words the finding of a positive reaction to gastric parietal cells is dependent both on the histological appearance and the disease in which the histological abnormality is found.

These findings support the view of Coghill and his colleagues (1965) that there might be several different aetiological factors in gastritis and that autoimmune mechanisms might only be of importance in some patients. Alternatively genetic factors might result in some individuals having the ability to produce circulating autoantibodies in response to tissue damage (Wright et al., 1966).

From a diagnostic point of view the finding of these antibodies indicates, not only that gastric damage is present, but that it is likely to be associated with impairment of intrinsic factor secretion and malabsorption of vitamin $B_{12}$-in other words to be associated with pernicious anaemia or latent pernicious anaemia. However,
$10-15 \%$ of patients with overt pernicious anaemia will have neither of the antibodies in their serum so that on their own they do not provide an adequate screening test for this disorder.

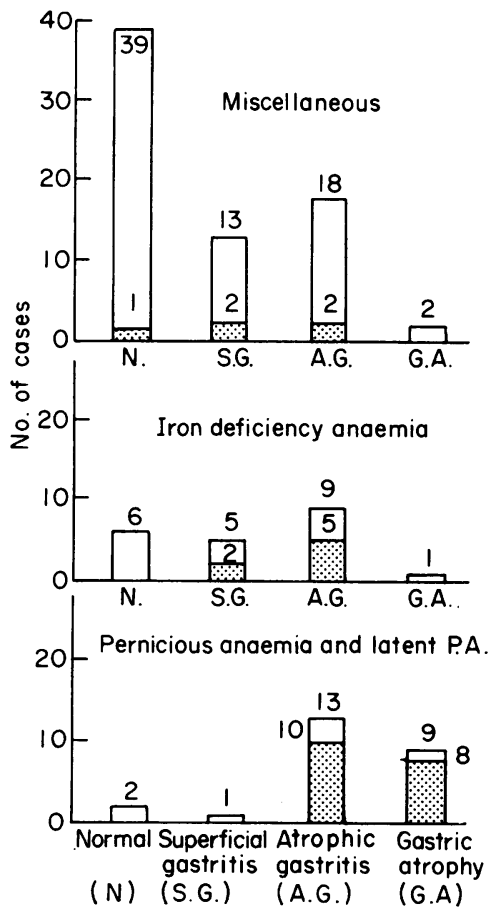

FIG. 2. The relationship of gastric parietal cell antibodies to the histology of the gastric mucosa in different groups of diseases (118 cases). Stippled columns, positive; open columns, negative. (Reproduced from Wright et al., 1966, by kind permission of the Editor.)

\section{Coeliac disease and idiopathic steatorrhoea}

The heavy infiltration of the intestinal villi with lymphocytes and plasma cells in coeliac disease raises the possibility that immunological mechanisms might be operative. If so this could be due to hypersensitivity to gluten but autoimmune processes might perpetuate the condition.

Although Malik and his colleagues (1964) showed, by means of immunofluorescence, that sera from some patients with untreated coeliac disease react with the jejunal mucosa this has not been generally confirmed (Rubin et al., 1965).

\section{Ulcerative colitis and Crohn's disease}

Broberger \& Perlmann (1959) were the first to suggest that autoimmune mechanisms might be of importance in ulcerative colitis when they found that children with this disease frequently have high-titre haemagglutinating antibodies in their sera to a phenol-water extract of human 
foetal colon. The antibody is also present in some adult patients with ulcerative colitis but positive reactions are unusual in health or in other disease (Asherson \& Broberger, 1961). Subsequently, Broberger \& Perlmann (1962) used the immunofluorescent technique to show that circulating antibodies to colon react with the colonic epithelial cell cytoplasm.

Using this technique we have detected the antibody in $16 \%$ of 273 patients with ulcerative colitis, but its presence could not be correlated with any of the clinical features of the disease including length of history, extent of colonic involvement, or the presence of extracolonic complications such as uveitis and sacroiliac involvement. They are confined to patients with ulcerative colitis and do not occur in healthy subjects or patients with other diseases (Harrison, 1965 ; Wright \& Truelove, 1966).

When the haemagglutination technique is used, the cells being coated with an antigen extracted from the faeces of germ-free rats (Perlmann et al., 1965). 16\% show high-titre reactions compared with $7 \%$ in a control group (Table 1 ).

TABLE 1

Antibodies to colon in ulcerative colitis and controls

\begin{tabular}{|c|c|c|c|c|}
\hline & \multicolumn{2}{|c|}{ Haemagglutination* } & \multicolumn{2}{|c|}{ Immunofluorescence } \\
\hline & $\begin{array}{c}\text { Positive } \\
\text { titre } 1 / 16+\end{array}$ & Total & Positive & Total \\
\hline Ulcerative colitis & $15(16 \%)$ & 95 & $43(16 \%)$ & 273 \\
\hline $\begin{array}{l}\text { Healthy control } \\
\text { subjects }\end{array}$ & $4(7 \cdot 1 \%)$ & 56 & Nil & 50 \\
\hline
\end{tabular}

* Rat faecal antigen kindly provided by Dr P. Perlmann.

Although haemagglutinating antibodies to ratfaecal antigens have been reported in a higher proportion of patients with ulcerative colitis by others (McGiven, Ghose, \& Nairn, 1967 ; Lagercrantz et al., 1966) they have sometimes been detected in healthy subjects and in patients with other diseases. Furthermore, as has been found with immunofluorescence, the antibodies cannot be correlated with clinical features of the disease, and may even persist after colectomy. The significance of these antibodies remains uncertain. They are clearly of little value in diagnosis. The lack of correlation with clinical features and the fact that they are not cytotoxic for colon cells in tissue culture (Broberger \& Perlmann, 1963) suggests that they are unlikely to be of direct importance in the pathogenesis of the lesion. The possibility that they might be indirectly concerned in pathogenesis is raised by the H interesting observation that there is a close relationship between the colonic antigen and an antigen present in some normal intestinal flora (Perlmann et al., 1965). It is conceivable therefore that an autoimmune response to the colon is either initiated or perpetuated by bacteria.

Of much greater interest in relation to pathogenesis is the finding of Perlmann \& Broberger (1963) that leucocytes from patients with ulcerative colitis are cytotoxic for foetal colon cells in tissue culture. Similar observations have been made by Watson, Quigley \& Bolt (1966). This suggests that cellular mechanisms mediated by lymphocytes, rather than circulating antibodies, may be responsible.

Despite repeated attempts autoantibodies to small intestinal structures have not been detected in Crohn's disease, although high-titre reactions to rat faecal antigen may occur (Lagercrantz et al., 1966). However the histological features with granuloma formation sugggest that anergy with impaired ability to produce circulating antibody might be a feature of this disease.

Ulcerative colitis and Crohn's disease share a number of extra-intestinal manifestations such as arthritis, ankylosing spondylitis, uveitis, liver disease, erythema nodosum and other skin eruptions. This suggests either that ulcerative colitis and Crohn's disease are generalized disorders in which the chief manifestation of the disease usually affects the intestine, or that the remote lesions are true complications of the intestinal disease. In either event immune mechanisms might be of importance in pathogenesis.

\section{Liver disease}

A detailed review of the immunological disorders affecting the liver is beyond the scope of the present discussion but I will refer briefly to a number of antibodies reacting with human or rat tissues which have been described recently in patients with liver disease as they are of considerable interest.

Walker and associates (1965) described an antibody reacting with mitochondria in gastric parietal cells, thyroid and distal tubules of the kidney. The antibody is found in practically all cases of primary biliary cirrhosis but not in patients with extrahepatic biliary obstruction. It is therefore of value in helping to make this important clinical distinction. The frequency with which it has been found in other forms of hepatocellular disease varies with the particular technique used but it occurs very much less frequently than in primary biliary cirrhosis (Doniach et al., 1966 ; Kantor \& Klatskin, 1967).

Johnson, Holborow \& Glynn (1965) and Whit- 
tingham, Mackay \& Irwin (1966) have described antibodies reacting with smooth muscle and renal glomeruli in patients with lupoid hepatitis. They are not found in systemic lupus erythematosus and relatively infrequently in patients with chronic active hepatitis without the L.E. cell phenomenon.

The significance of these antibodies in relation to the pathogenesis of liver disease remains obscure but they appear to be useful in diagnosis.

\section{Conclusions}

To date evidence in man for the operation of autoimmune mechanisms in alimentary disease has largely depended on the demonstration of circulating autoantibodies but if implicated at all in pathogenesis their role is likely to be secondary. It is possible that they act synergistically with cellular mechanisms mediated by lymphocytes but technical difficulties have limited the study of these processes.

Whatever their importance in pathogenesis it seems likely that some of these antibodies may be of value to the clinician as an aid to diagnosis.

\section{References}

Adams, J.F., Glen, A.I.M., Kennedy, E.H., Mackenzie, I.L., Morrow, J.M., ANDERSON, J.R., GRAY, K.G. \& Middleton, D.G. (1964) The histology and secretory changes in the stomach in patients with autoimmunity to gastric parietal cells. Lancet, i, 401.

Ardeman, S. \& Chanarin, I. (1963) A method for the assay of human gastric intrinsic factor and for the detection and titration of antibodies against intrinsic factor. Lancet, ii, 1350.

Asherson, G.L. \& Broberger, O. (1961) Incidence of haemagglutinating and complement-fixing antibodies. Brit. med. J. i, 1429.

Broberger, O. \& Perlmann, P. (1959) Autoantibodies in human ulcerative colitis. J. exp. Med. 110, 657.

Broberger, O. \& PerlmanN, P. (1962) Demonstration of an epithelial antigen in colon by means of fluorescent antibodies from children with ulcerative colitis. $J$. exp. Med. 115, 13.

Broberger, O. \& PerlmanN, P. (1963) In vitro studies of ulcerative colitis. I. Reactions of patients' serum with human fetal colon cells in tissue cultures. J. exp. Med. 117, 705.

Buchanan, W.W., Cox, A.G., Harden, R.McG., Glen, A.I.M., ANDERSON, J.R. \& GRAY, K.R. (1966) Gastric studies in Sjögren's syndrome. Gut, 7, 351.

Coghill, N.F., Doniach, D., RoIt, I.M., Mollin, D.L. \& Williams, A.W. (1965) Autoantibodies in atrophic gastritis. Gut, 6, 48.

DAGG, J.H., GoldberG, A., Gibis, W.N. \& ANDERson, J.R. (1966) Detection of latent pernicious anaemia in iron deficiency anaemia. Brit. med. J. ii, 619.

DonIACH, D., RoITT, I.M. \& TAYLOR, K.B. (1963) Autoimmune phenomena in pernicious anaemia. Serological overlap with thyroiditis, thyrotoxicosis and systemic lupus erythematosis. Brit. med. J. i, 1374.

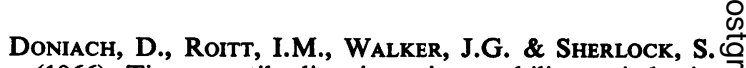
(1966) Tissue antibodies in primary biliary cirrhosis, ฏ) active chronic (Lupold) hepatitis, cryptogenic cirrhosis and other liver diseases and their clinical implications. $\frac{T}{\mathrm{D}}$ Clin. exp. Immunol. 1, 237.

Fisher, J.M., MACKaY, I.R., TAYlOR, K.B. \& UNGeR, B. $\stackrel{\complement}{\complement}$ (1967) An immunological study of categories of gastritis. $\rightrightarrows$ Lancet, i, 176.

HARRISON, W.J. (1965) Autoantibodies against intestinal $\frac{-}{\square}$ and gastric mucous cells in ulcerative colitis. Lancet, i, 1346 .

IRVINE, W.J. (1963) Gastric antibodies studied by fluorescence microscopy. Quart. J. exp. Physiol. 48, 427.

Irvine, W.J., Davies, S.H., Teitelbaum, S., Delamore, 凤 I.W. \& Williams, A.W. (1965) The clinical and patho- $\infty$ logical significance of gastric parietal cell antibody. $\overrightarrow{0}$ Ann. N.Y. Acad. Sci. 124, 657.

Johnson, G.D., Holborow, E.J. \& GlYNN, L.E. (1965) Antibody to smooth muscle in patients with liver disease. $\sigma$ Lancet, ii, 878.

Kantor, F.S. \& KLATSKin, G. (1967) Serological diagnosis of primary biliary cirrhosis: a potential clue to pathogenesis. Trans. Ass. Amer. Phycns, 80, 267.

Lagercrantz, R., Hammarström, S., Perlmann, P. \& cं GustafsSON, B.E. (1966) Immunological studies in $\vec{G}$ ulcerative colitis. Clin. exp. Immunol. 1, 263.

Malik, G.B., Watson, W.C., Murray, D. \& Cruickshank, of B. (1964) Immunofluorescent antibody studies in idiopathic steatorrhoea. Lancet, i, 1127.

McGiven, A.R., Ghose, T. \& NaIRN, R.C. (1967) Aut antibodies in ulcerative colitis. Brit. med. J. ii, 19.

Perlmann, P. \& Broberger, O. (1963) In vitro studies ff ulcerative colitis. II. Cytotoxic action of white blood cells from patients on human fetal colon cells. $J$. ex区 Med. 117, 717.

Perlmann, P., Hammarström, S., Lagercrantz, R. Gustafsson, B.E. (1965) Antigen from colon of germ-fre rats and antibodies in human ulcerative colitis. An $\infty$ N.Y. Acad. Sci. 124, 377.

Rubin, W., Fauci, A.S., Sleisenger, M.H. \& Jefrriè่, G.H. (1965) Immunofluorescent studies in adult celiac disease. J. clin. Invest. 44, 475.

SchWARTZ, M. (1960) Intrinsic factor antibody in serum from patients with pernicious anaemia. Lancet, ii, 1263.

TAYLOR, K.B. (1959) Inhibition of intrinsic factor by pernicious anaemia sera. Lancet, ii, 106.

TAYlor, K.B., RoITt, I.M., Doniach, D., Couchman, K.G. \& Shapland, C. (1962) Autoimmune phenomena in pernicious anaemia: Gastric antibodies. Brit. med. $J$. ii, 1347.

Walker, J.G., Doniach, D., RoITT, I.M. \& Sherlock, S. (1965) Serological tests in diagnosis of primary biliary cirrhosis. Lancet, i, 827.

WANGel, A.G. \& Schiller, K.F.R. (1966) The diagnostic significance of antibody to intrinsic factor. Brit. med. $J$. i, 1274.

WATSON, D.W., Quigley, A. \& BolT, R.J. (1966) Effect of lymphocytes from patients with ulcerative colitis on $ᄋ$ human colon epithelial cells. Gastroenterology, 51, 985 .

Whittingham, S., Mackay, I.R. \& IRWIN, J. (1966) Autoimmune hepatitis. Lancet, $\mathbf{i}, 1333$.

Wright, R.S.T. \& Truelove, S.C. (1966) Auto-immune reactions in ulcerative colitis. Gut, $7,32$.

Wright, R., Whitehead, R., Wangel, A.G., Salem, S.N. N \& SCHILler, K.F.R. (1966) Autoantibodies and micro- $N$ scopic appearance of gastric mucosa. Lancet, $i, 618$. 